\title{
Design and Morphology Characterization of Biopolymer Blend-ZnO Nanocomposites Coated Cu-Ni-Mo-based Steel Foam
}

\author{
Nuray Beköz Üllen ${ }^{1 *}$ \\ ${ }^{1 *}$ Istanbul University-Cerrahpaşa, Faculty of Engineering, Departmant of Metallurgical and Material Engineering, İstanbul, Turkey, (ORCID: 0000-0003-2705-2559), \\ nbekoz@iuc.edu.tr
}

(International Conference on Design, Research and Development- 15 - 18 December 2021)

(DOI: 10.31590/ejosat.1039292)

ATIF/REFERENCE: Beköz Üllen, N. (2021). Design and Morphology Characterization of Biopolymer Blend-ZnO Nanocomposites Coated Cu-Ni-Mo-based Steel Foam. European Journal of Science and Technology, (32), 339-345.

\begin{abstract}
Recent developments have been focused on the fabrication and application of metal-metal oxide nanocomposites coated steel foam for nanomaterials, which can have excellent surface morphology and mechanical properties than conventional materials. In this study, a novel 3 dimensional (3D) biopolymer blend-ZnO nanocomposites coated $\mathrm{Cu}-\mathrm{Ni}$-Mo-based steel foam was designed and prepared. The objective of this work was to investigate the deposition of the nanofilm by immersion of the steel foam into a solution containing ZnO nanostructures and to determine the effect of the surface coating of biopolymer blend-ZnO nanocomposites onto the $\mathrm{Cu}-\mathrm{Ni}$-Mo-based steel foam. A low-cost and easy-to-use dip-coating method was preferred to obtain uniform and high quality coating layers. With this approach, the nanocoatings were prepared at $25{ }^{\circ} \mathrm{C}$ and low contact time $(\approx 10 \mathrm{~min})$. X-ray diffraction $(\mathrm{XRD})$, scanning electron microscopy (SEM), and stereo microscope analysis methods were used to demonstrate surface and chemical properties of the tragacanth gum / chitosan blend encapsulated $\mathrm{ZnO}$ nanocomposites (TG/CH/ZnO NPs) coated Cu-Ni-Mo based steel foam. According to the SEM and stereo microscope images, the prepared 3D random shape with irregular $\mathrm{ZnO} \mathrm{NPs}$ on the surface of the $\mathrm{Cu}-\mathrm{Ni}-\mathrm{Mo}$ based steel foam were formed. Furthermore, the mean surface roughness values of uncoated steel foam and TG/CH/ZnO NPs coated steel foam were measured as $4.48 \mu \mathrm{m}$ and $4.61 \mu \mathrm{m}$, respectively. Additionally, the RGB pixel of the SEM micrograph of the coated steel foam was analyzed to investigate the effect of coating materials on the surface. Due to cost-efficient and green fabrication of the nanocoating, it has a significant potential to be a promising nanomaterial in biomedical applications.
\end{abstract}

Keywords: $\mathrm{ZnO}$ nanocomposite, Steel foam, Nanocoating.

\section{Biyopolimer karışım-ZnO Nanokompozit Kaplamalı Cu-Ni-Mo-bazlı Çelik Köpüğün Tasarımı ve Morfoloji Karakterizasyonu}

Öz

Son gelişmeler, nanomalzemeler için geleneksel malzemelere göre mükemmel yüzey morfolojisi ve mekanik özelliklere sahip olabilen metal-metal oksit nanokompozitler kaplı çelik köpügün üretimi ve uygulamasına odaklanmıştır. Bu çalışmada, Cu-Ni-Mo esaslı yeni bir 3 boyutlu (3B) biyopolimer karışımı-ZnO nanokompozitleri kaplanmış çelik köpük tasarlandı ve hazırlandı. Bu çalışmanın amacı, çelik köpüğün ZnO nanoyapıları içeren bir çözeltiye daldırılmasıyla nanofilmin birikmesini araştırmak ve biyopolimer karışımı-ZnO nanokompozitlerinin yüzey kaplamasının $\mathrm{Cu}-\mathrm{Ni}$-Mo bazlı çelik köpük üzerindeki etkisini belirlemekti. Düzgün ve kaliteli kaplama tabakaları elde etmek için düşük maliyetli ve kullanımı kolay bir daldırma kaplama yöntemini tercih edilmiştir. Bu yaklaşımla, nanokaplamalar $25^{\circ} \mathrm{C}^{\prime} \mathrm{de}$ ve düşük temas süresinde $(\approx 10 \mathrm{dk})$ hazırlanmıştır. X-1şını kırınımı (XRD), taramalı elektron mikroskobu (SEM) ve stereo mikroskop, kitre sakızı / kitosan karışımı ile kapsüllenmiş ZnO nanokompozitlerinin (TG/CH/ZnO NP'ler) kaplanmış $\mathrm{Cu}-\mathrm{Ni}$-Mo bazlı çelik köpüğün yüzey ve kimyasal özelliklerini göstermek için kullanıldı. SEM ve stereo mikroskop görüntülerine göre, $\mathrm{Cu}-\mathrm{Ni}-\mathrm{Mo}$ esaslı çelik köpüğün yüzeyinde düzensiz ZnO NP'leri ile hazırlanan 3 boyutlu rastgele yapı oluşturulmuştur. Ayrıca kaplanmamış çelik köpüğün ve TG/CH/ZnO NPs kaplı çelik köpüğün ortalama yüzey pürüzlülük değerleri sırasıyla $4.48 \mu$ m ve 4.61 $\mu \mathrm{m}$ olarak ölçülmüştür. Ayrıca, kaplama malzemelerinin yüzey üzerindeki etkisini araştırmak için kaplanmış çelik köpüğün SEM mikrografının RGB pikselleri analiz edilmiştir. Nanokaplamanın düşük maliyetli ve çevre dostu üretimi nedeniyle, biyomedikal uygulamalarda umut verici bir nanomalzeme olma potansiyeline sahiptir.

Anahtar Kelimeler: ZnO nanokompozit, Çelik köpük, Nanokaplama.

*Corresponding Author: nbekoz@iuc.edu.tr 


\section{Introduction}

With unique developments in nanocoatings, metal oxide nanocoating plays a key role in creative technologies for multidisciplinary applications (Welegers et al., 2021). Among several metal oxide nanocomposites, $\mathrm{ZnO}$ nanocomposites are the most leading materials of current developments with superior properties such as biological, mechanical, optical, and electrochemical properties (Najm, 2021; Yang et al., 2021; Rajkumar and Sarma, 2021; Tariq et al., 2021). In particular, ZnO nanocomposites have been fabricated using different methods such as wet chemical, sonication, and microwave methods to obtain uniform nanomaterials (Wagener et al., 2011; Priya et al., 2020; Javed et al., 2020). Considering biopolymer blends have been used as attractive matrixes in several applications with different advantages such as biodegradability, biocompatibility, antimicrobial, antifungal, low-cost, and good transparency.

Metal foams are a new type of material that was first started to be produced in the $1950 \mathrm{~s}$ and attracted attention among lightweight materials with the developments in recent years (Banhart, 2001). Among metallic foams, especially steel foams stand out with their low cost, high mechanical and thermal damping, lightness, and specific hardness properties (Smith et al., 2012). For these reasons, steel foams are becoming the most promising class of materials in the scientific and industrial areas. There are many studies in the literature on the production, characterization, and investigation of steel foams' properties (Jain et al, 2020; Sazegaran, 2021; Joshi et al., 2015; Yu et al., 1998; Guo et al., 2016). However, since steel foams are a new type of material, they have properties that need to be investigated and developed. It is necessary to examine the coating properties in order to make the use of this new material more widespread and to improve properties such as corrosion resistance and surface functionality (Smith et al., 2012; Banhart, 2001; Shirzadi et al., 2004). Therefore, $\mathrm{Cu}-\mathrm{Ni}-\mathrm{Mo}$ based steel foam produced by the powder metallurgy method was used as the material to be coated in this research. The powder metallurgy method is a prominent method in the production of metallic foam due to its ease, controllability, and final product quality (Beköz Üllen and Karabulut, 2021). The commercial name of the $\mathrm{Cu}-\mathrm{Ni}-\mathrm{Mo}$-based steel alloy used in the study is Distaloy AB. This steel is primarily used in automotive parts, as well as in the aerospace and machinery industries (Beköz and Oktay, 2014). In this study, a novel tragacanth gum / chitosan blend encapsulated $\mathrm{ZnO}$ nanocomposites (TG/CH/ZnO NPs) coated $\mathrm{Cu}-\mathrm{Ni}-\mathrm{Mo}$ based steel foam was developed. The surface morphology and chemical property of the $\mathrm{TG} / \mathrm{CH} / \mathrm{ZnO}$ NPs coated $\mathrm{Cu}-\mathrm{Ni}-\mathrm{Mo}$ based steel foam were investigated using different techniques such as X-ray diffraction (XRD), scanning electron microscopy (SEM), and stereo microscope techniques.

\section{Material and Method}

\subsection{Materials}

Tragacanth gum (molecular weight:840 kDa) and chitosan (molecular weight:141 kDa) were purchased from Sigma Aldrich Company (Germany). Zincnitrate hexahydrate $\left.\mathrm{Zn}\left(\mathrm{NO}_{3}\right) 2 \cdot 6 \mathrm{H}_{2} \mathrm{O}\right)$, glacial acetic acid (glacial $100 \%$, pro analysis), and sodium hydroxide $(\mathrm{NaOH})$ were purchased from Merck Company (Germany). The chemical content of $\mathrm{Cu}-\mathrm{Ni}-\mathrm{Mo}$-based steel powders was $1.75 \mathrm{wt} \% \mathrm{Ni}, 1.5 \mathrm{wt} . \% \mathrm{Cu}, 0.5 \mathrm{wt} . \% \mathrm{Mo}$, and the balanced Fe. Space holder (carbamide), binder (paraffin wax), lubricants (fine graphite and zinc stearate) were supplied from Merck Company (Germany).

\subsection{Characterization}

The surface characterization and chemical properties of $\mathrm{TG} / \mathrm{CH} / \mathrm{ZnO} \mathrm{NPs}$ and nanocomposite coated $\mathrm{Cu}-\mathrm{Ni}-\mathrm{Mo}$ based steel foam were determined using different techniques such as stereo microscope, Scanning Electron Microscopy (SEM, FEI QUANTA 450) with a double-coated, $8 \mathrm{mmW} \times 20 \mathrm{~mL}$, X-ray diffraction (XRD) with $\mathrm{Cu} \mathrm{K} \alpha$ radiation at $40 \mathrm{kV}$ and $15 \mathrm{~mA}$. The RGB results were recorded using the smartphone (Casper VIA F20) that had a screen size of 6.55 inches and a screen resolution of $720 \times 1600$ pixels.

\subsection{Preparation of Tragacanth Gum-Chitosan- ZnO Nanocomposites}

In previous study, the preparation process of the green $\mathrm{ZnO}$ nanocomposites was given (Kolatoglu et al., 2020). The nanostructure was prepared using a sonochemical method at room temperature. $0.025 \mathrm{~g}$ of tragacanth gum was dissolved in $12.5 \mathrm{ml}$ of distilled water for $2 \mathrm{~h}$. $0.025 \mathrm{~g}$ of chitosan was dissolved in 12.5 $\mathrm{ml}$ of glacial acetic acid-water solution $(2 / 48, \mathrm{v} / \mathrm{v})$. Tragacanth gum and chitosan solutions were mixed and $0.1 \mathrm{M}$ of $\mathrm{Zn}$ $\left(\mathrm{NO}_{3}\right)_{2} \cdot 6 \mathrm{H}_{2} \mathrm{O}$ solution and $0.2 \mathrm{M}$ of $\mathrm{NaOH}$ solution were added in the polymer blend. Then, $0.1 \mathrm{M}$ of $\mathrm{NaOH}$ solution was added drop by drop to the solution and sonicated at $25^{\circ} \mathrm{C}$ for $40 \mathrm{~min}$. The sample was first filtered using a sterile filter with a $0.22 \mu \mathrm{m}$ pore size to obtain $\mathrm{ZnO}$ nanocomposites.

\subsection{Preparation of Cu-Ni-Mo-based Steel Foam}

Details on the preparation processes of $\mathrm{Cu}-\mathrm{Ni}-\mathrm{Mo}$ based steel foam are reported in the previous paper (Bekoz and Oktay, 2013). The method briefly consists of 4 main steps: preparation of powders, preparation of green compact, removal of space holders, and sintering. A schematic representation of the preparation of the $\mathrm{Cu}-\mathrm{Ni}$-Mo based steel foam is given in Figure 1. Firstly, the powders, binder, lubricant, and space holders were mixed in the turbula type mixer for one hour until the space holders were completely coated. Then, the mixture was compacted with a hydraulic press to obtain a green compact with a diameter of 10 $\mathrm{mm}$ and a height of $12 \mathrm{~mm}$. Next, the removal of the space holders in the compact steel structure was done in distilled water at room temperature. Finally, $\mathrm{Cu}-\mathrm{Ni}$-Mo-based steel foam was obtained by sintering in a laboratory tube furnace at $1150{ }^{\circ} \mathrm{C}$ for 60 minutes.

\subsection{Preparation of Nanocomposite Coated $\mathrm{Cu}-\mathrm{Ni}$ - Mo-based Steel Foam}

In order to coat the produced steel foams more easily, the cutting process with Electrical Discharge Machining (EDM) was applied. The photograph and process parameters of the $\mathrm{Cu}-\mathrm{Ni}-\mathrm{Mo}$ based steel foam before and after the cutting process are given in Figure 2. After the cutting process was completed, the dust caused by the cutting process on the surface was removed by compressed air. $\mathrm{Cu}-\mathrm{Ni}$-Mo-based steel foam pieces sliced in $0.5 \mathrm{~cm}$ thickness were dipped in the $\mathrm{TG} / \mathrm{CH} / \mathrm{ZnO} \mathrm{NPs}$ solution for $5 \mathrm{~min}$ at room temperature and then dried at $50{ }^{\circ} \mathrm{C}$ for 3 hours. According to the weight difference results of the uncoated foam before and after coating, $2.95 \mathrm{mg}$ of solution was loaded into the foam. 

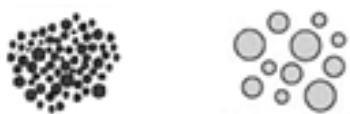

\section{$\mathrm{Cu}-\mathrm{Ni}-\mathrm{Mo}$ Carbamide} based steel

powder

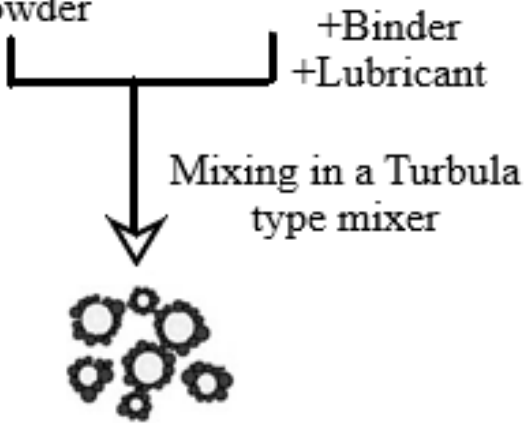

Carbamide particles coated

with steel powders

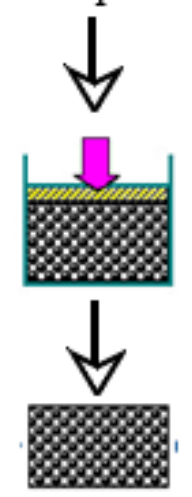

Compacting in a hydraulic press

\section{Green steel structure}

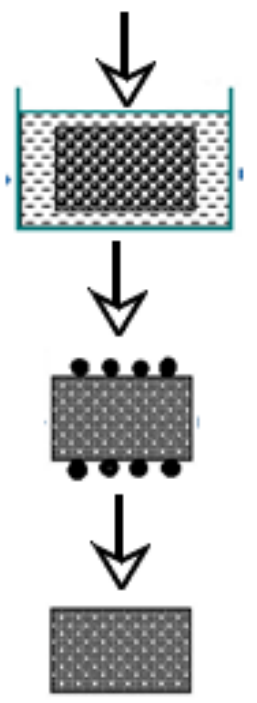

\section{Removing of carbamide}

Sintering in a

laboratory tube furnace

\section{$\mathrm{Cu}-\mathrm{Ni}-\mathrm{Mo}$ based steel foam}

Figure 1. Preparation of Cu-Ni-Mo based steel foam

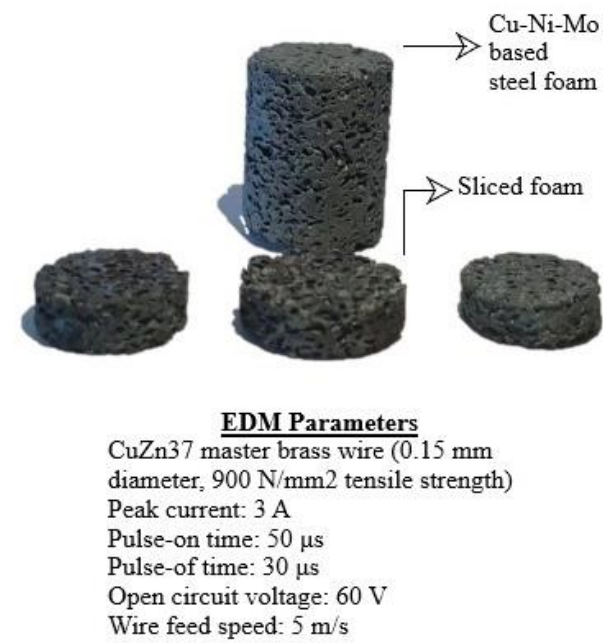

Figure 2. Photograph of produced and sliced $\mathrm{Cu}$-Ni-Mo based steel foam and cutting process parameters

\section{Results and Discussion}

\subsection{Characterization of Tragacanth Gum- Chitosan- ZnO Nanocomposite}

In previous study, XRD and SEM techniques were used to demonstrate surface and chemical properties of the $\mathrm{TG} / \mathrm{CH} / \mathrm{ZnO}$ NPs. XRD analysis was used to determine the structural and crystalline phases of $\mathrm{TG} / \mathrm{CH} / \mathrm{ZnO}$ NPs. In Figure 3, SEM micrograph of $\mathrm{TG} / \mathrm{CH} / \mathrm{ZnO} \mathrm{NPs}$ revealed the uniform morphology with self-assembled monolayer of prism shaped particles. Furthermore, prepared $\mathrm{TG} / \mathrm{CH} / \mathrm{ZnO} \mathrm{NPs}$ have a homogeneous distribution with $\mathrm{ZnO}$ particles below $100 \mathrm{~nm}$ in size (Kolatoğlu et al., 2020).

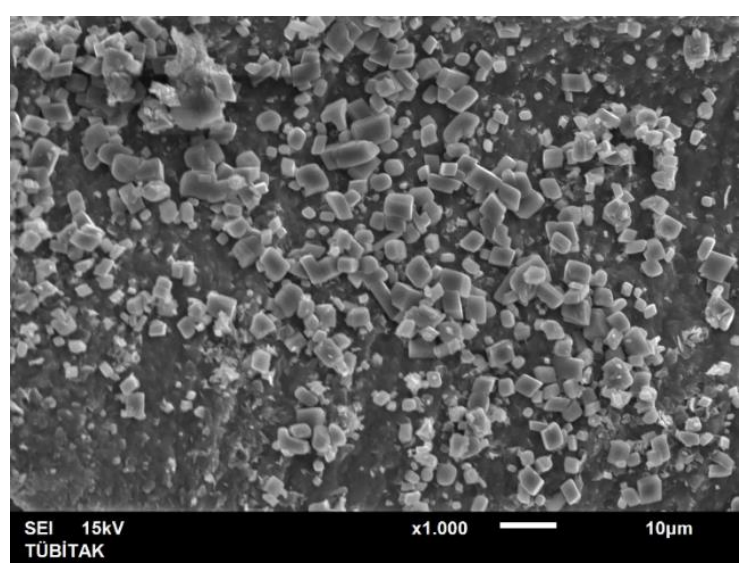

Figure 3. The SEM micrograph of $T G / C H / Z n O N P s$.

In Figure 4 , the prepared $\mathrm{TG} / \mathrm{CH} / \mathrm{ZnO}$ NPs patterns were exhibited three predominant crystalline peaks $2 \theta$ value at $13^{\circ}, 31^{\circ}$, $35^{\circ}$ and $40^{\circ}$ which indexed to the planes $\{102\},\{100\},\{002\}$, and $\{101\}$, respectively (JCPDS-897102) (Kolatoğlu et al., 2020). The Scherrer's equation was used to calculate the average crystallite size of the particles (Singh et al, 2016).

$$
\mathrm{D}=0.94 \lambda / \beta \cos \theta
$$

Where, D: the crystallite size perpendicular to the reflecting planes, $\lambda$ : wavelength of X-rays, $\beta$ : the broadening of diffraction 
line at half of its maximum intensity at half maximum, and $\theta$ : the angle of diffraction. The crystallite size of the ZnO NPs was calculated to be $16.71 \mathrm{~nm}$ using the Scherrer's equation.

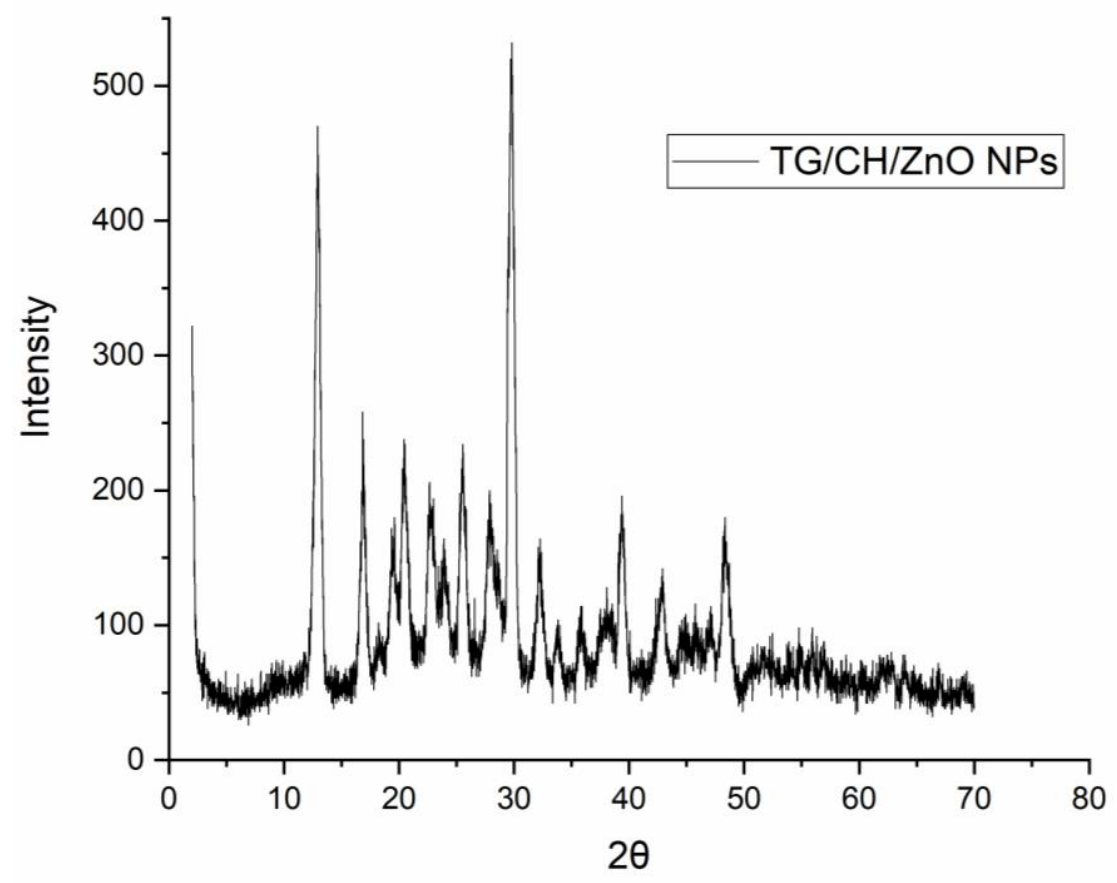

Figure 4. XRD analysis of TG/CH/ZnO NPS.

\subsection{Characterization of $\mathrm{Cu}-\mathrm{Ni}-\mathrm{Mo}$-based Steel Foam}

$\mathrm{Cu}-\mathrm{Ni}$-Mo-based steel foams having about $72 \%$ porosity were produced by the powder metallurgy technique. Figure 5 shows the stereo microscope image of pores structures. SEM image of steel foam is shown in Figure 6. The final state morphology of the pores of the sintered $\mathrm{Cu}-\mathrm{Ni}$-Mo based steel foams has resembled the initial shape of the carbamide particles. The foam consists of $72 \%$ total porosity, with $55 \%$ open and $17 \%$ closed. The mean equivalent spherical diameter and mean sphericity, examined from the SEM image using image analyzer software, were determined as $612 \mu \mathrm{m}$ and 0.55 , respectively.

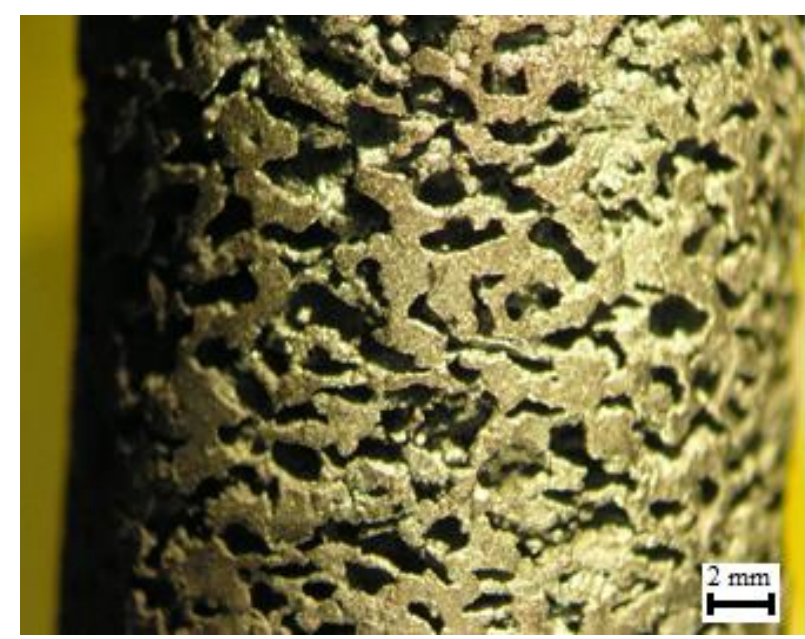

Figure 5. The stereo microscope image of $\mathrm{Cu}$-Ni-Mo based steel foam

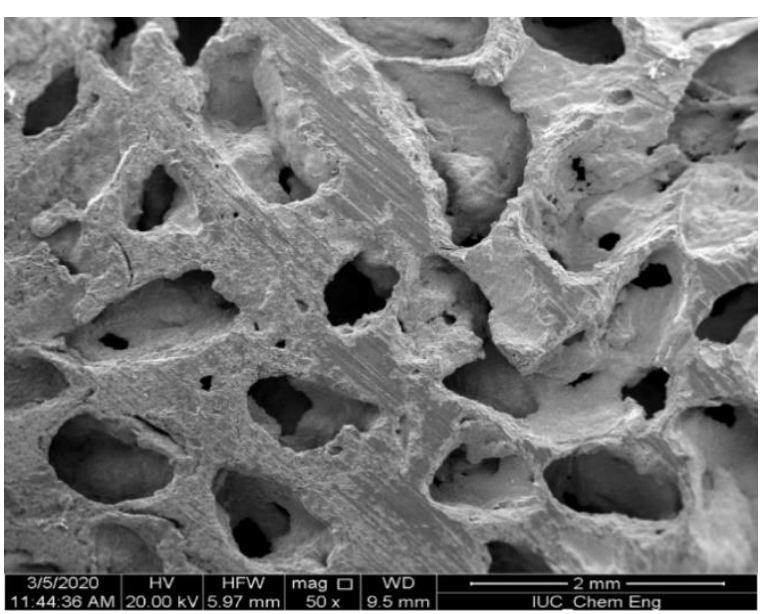

Figure 6. The SEM images of Cu-Ni-Mo based steel foam

\subsection{Characterization of Nanocomposite Coated Low Alloyed Steel Foam}

In order to better understand the post-coating structure, SEM image of the pre-coating structure is given in Figure 7. SEM images of the coated samples at different magnifications are given in Figure 8, Figure 9 and Figure 10. The change in the coated surface of the steel foam compared to the uncoated surface is observed from the images. Looking at the images at larger magnifications, it can be said that the coating structure is in a geometric form with sharp corners. There are a few published reports on coating of stainless steel foams. Karakuş et al. (2020a), studied the surface behavior of $\mathrm{ZnO}$ nanoparticles coated 17-4 PH stainless steel foam, and understood from the SEM images that the steel surface is homogeneously coated with the nanostructure, 
with the branched structure formed after the coating. In another study of the Karakuş et al. (2021), investigated the surface behavior of coated 17-4 PH stainless steel foam with KappaCarrageenan/PVA/ES nanobiocomposite, and similar results have been reported.

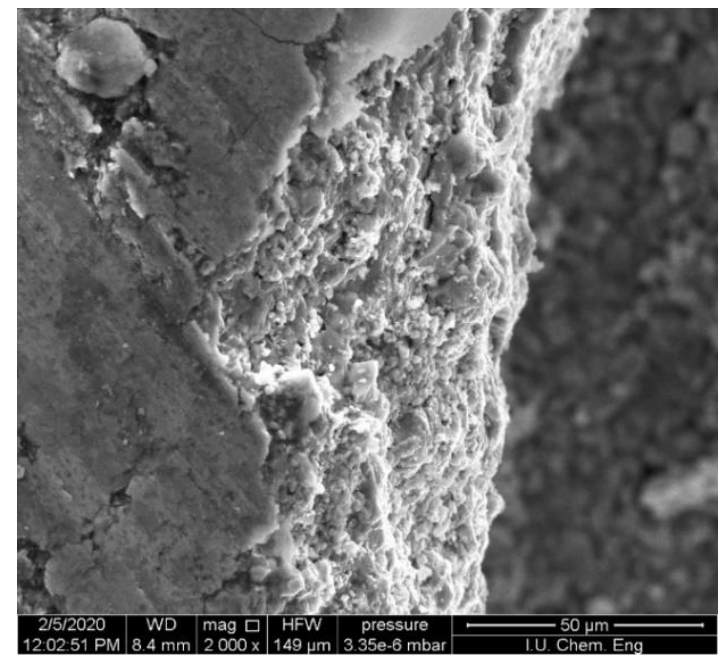

Figure 7. The SEM images of uncoated Cu-Ni-Mo based steel foam

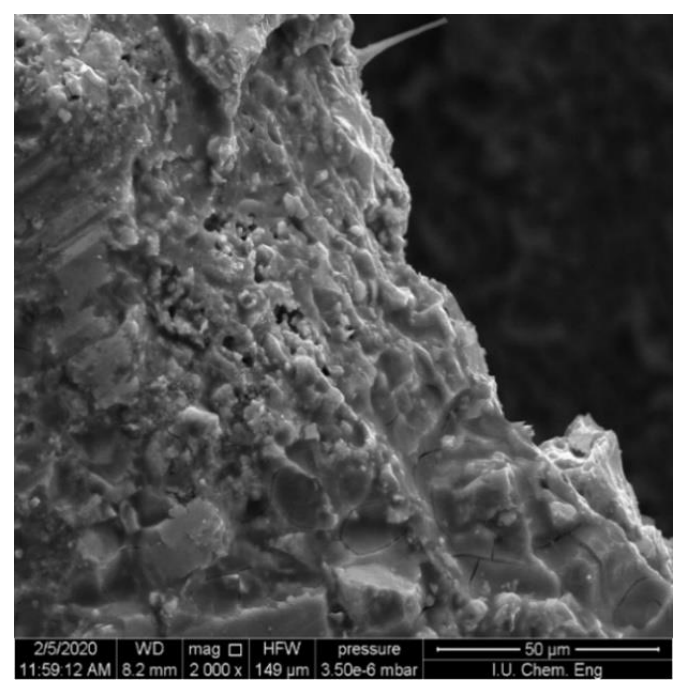

Figure 8. The SEM image of coated surface at $x 2000$ magnification

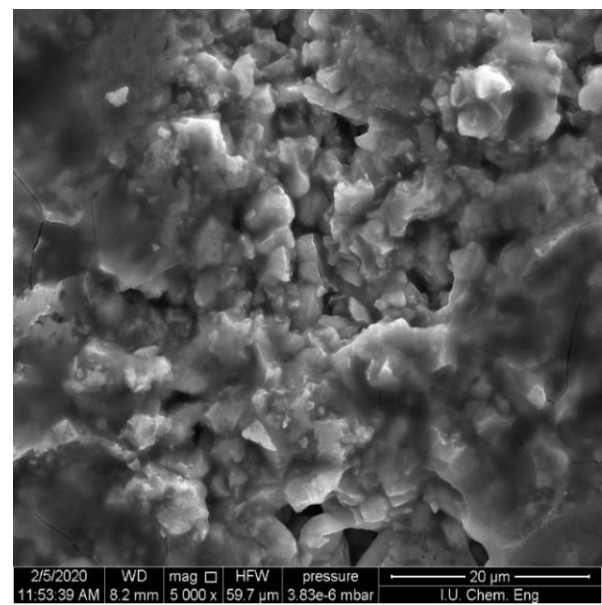

Figure 9. The SEM image of coated surface at $\times 5000$ magnification

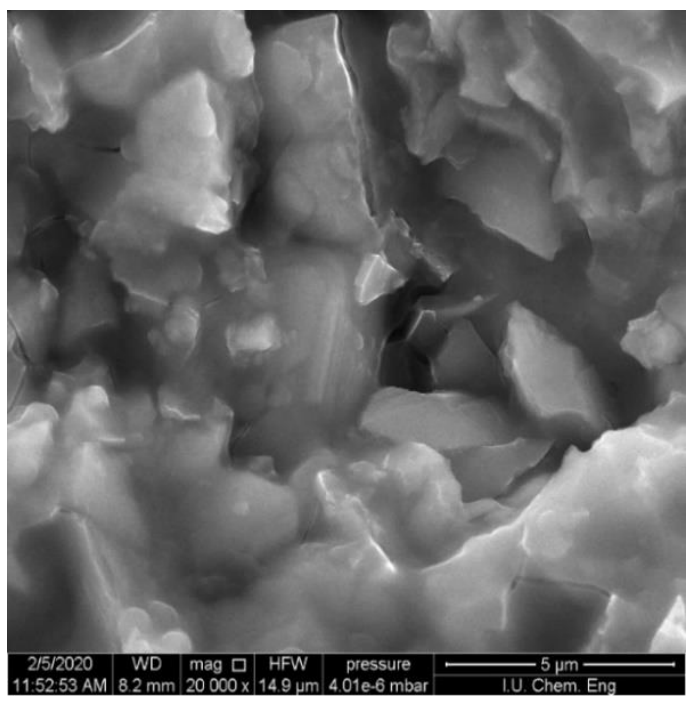

Figure 10. The SEM image of coated surface at $x 20000$ magnification

The mean surface roughness values of uncoated steel foam and $\mathrm{TG} / \mathrm{CH} / \mathrm{ZnO}$ NPs coated steel foam were measured as 4.48 $\mu \mathrm{m}$ and $4.55 \mu \mathrm{m}$, respectively. The coating thickness value was measured as approximately $21 \mu \mathrm{m}$ with an optical microscope. A closer view of the pore walls of the coated steel foams was presented in Figure 11. The presence of very prominent micropores in the cell walls was detected. These micropores affect the properties of the porous structure by providing communication between macropores. No cracks were detected along with the interface during the coating process of the steel foam. The surface properties of coated 17-4 PH stainless-steel foam with $\mathrm{CMC} / \mathrm{Chitosan}-\alpha-\mathrm{Fe}_{2} \mathrm{O}_{3}$ nanoparticles (NPs) was studied by Karakuş et al. (2020b), the authors reported that the average surface roughness and coating thickness values coated stainless steel foam to be between $4.59-5.91 \mu \mathrm{m}$ and 15 and 30 $\mu \mathrm{m}$, respectively.

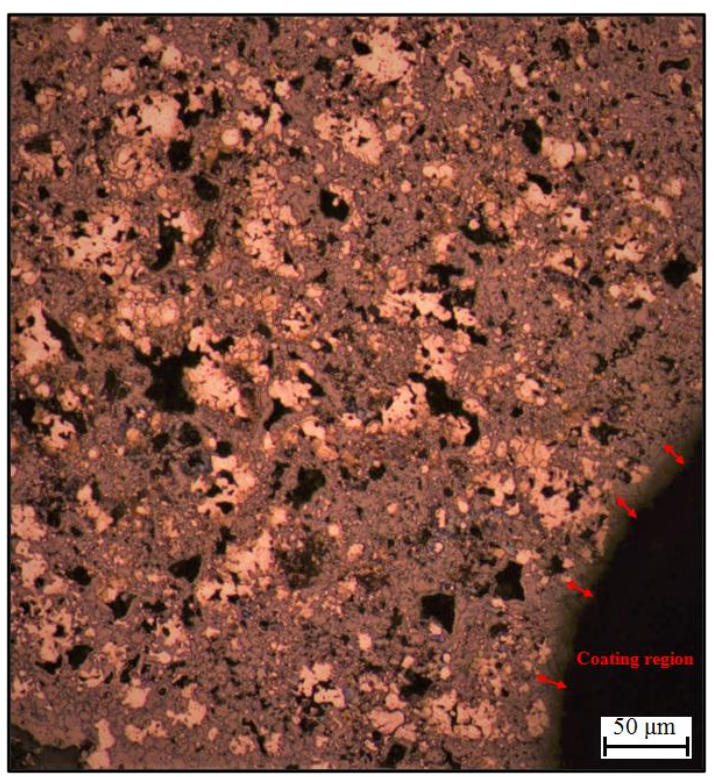

Figure 11. Cross-sectional surface microstructure of the TG/CH/ZnO NPs coating on the $\mathrm{Cu}$-Ni-Mo based steel foam substrate 

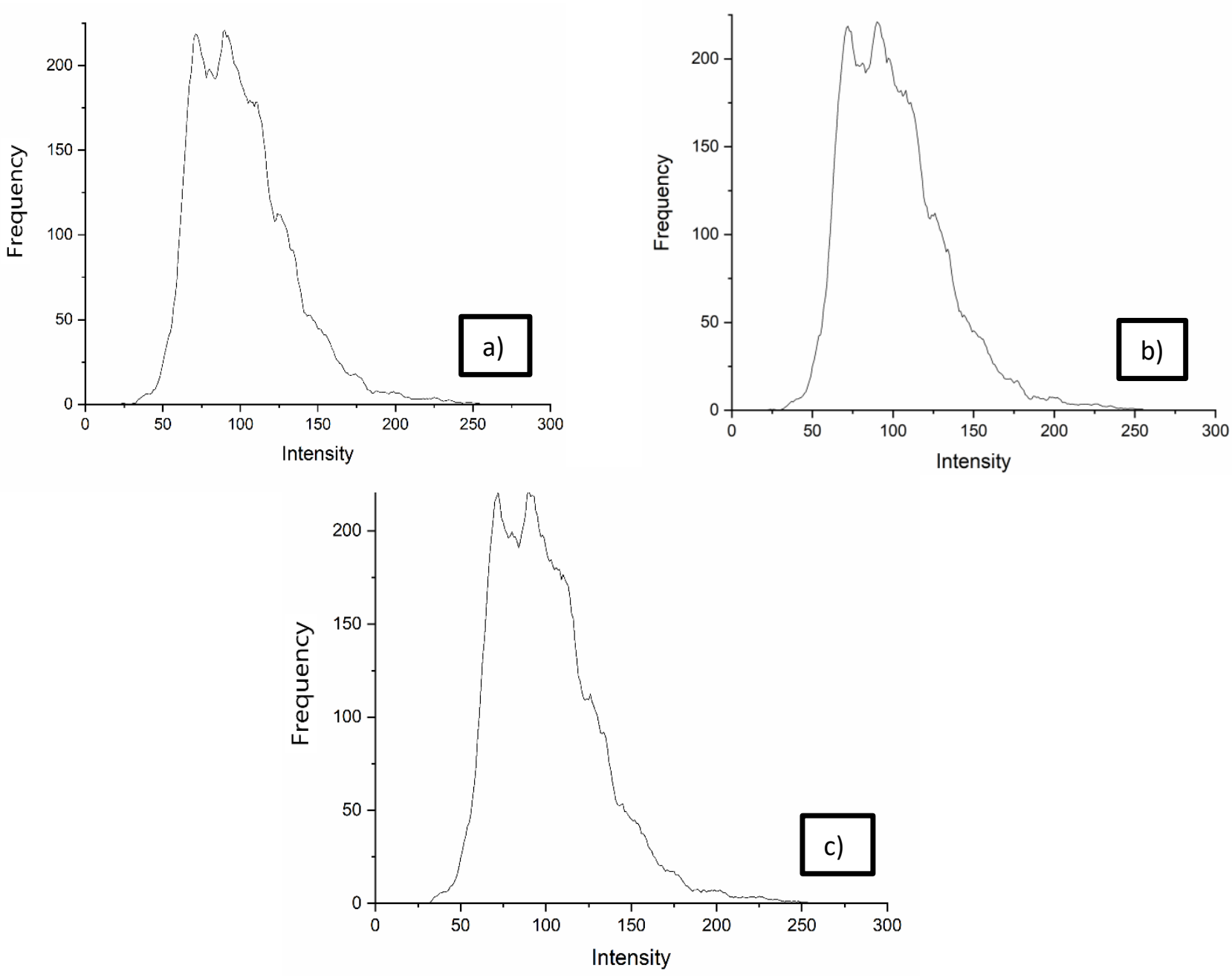

Figure 12. RGB analysis a) red b) green c) blue color of the SEM image of coated surface.

In this study, the RGB pixel of the SEM micrograph of the coated steel foam was analyzed to investigate the effect of coating materials on the surface. The color intensity of RGB image of the coated foam was related to the variation of the recombination probabilities from different areas of the SEM mapped part (Rodriguez et al., 2021). With this approach, it was found that SEM/RGB images exhibited a close result in red (101.01), blue (101.01), and green (100.99) intensities due to the material coating process. Finally, a uniform morphology was observed without a significant sharp increase on the surface of the region, corresponding to the coating and the process successfully happened.

\section{Conclusions and Recommendations}

Biopolymer blend-ZnO nanocomposite was successfully coated on $\mathrm{Cu}$-Ni-Mo-based steel foam for the first time in this study. The surface property of the prepared biopolymer blend- $\mathrm{ZnO}$ nanocomposite was successfully coated on Cu-Ni-Mo-based steel foam was tested using the SEM image based RGB color method. The nanoparticles had a prism shape and the crystal size of the nanostructure was determined as $16.71 \mathrm{~nm}$. It was observed that the shape of the nanoparticles was preserved after the coating, and the surface was uniformly coated with an average thickness of $21 \mu \mathrm{m}$.

The coating characteristic of metal foams is not only affected by the properties of the foam but also depends on the properties of the material to be coated, namely the substrate. The effect of the use of steel powders containing different alloying elements on the coating properties should be investigated. The coating behavior of steel foams has become a very important subject for research with the wide range of applications of these materials. It is hoped that this study will help researchers working on this subject.

\section{Acknowledge}

This work was supported by Scientific Research Projects Coordination Unit of Istanbul UniversityCerrahpaşa. Project number: BYP-2021-35529

I would like to acknowledge Assoc. Prof. Dr. Selcan Karakuş and Res. Asst. Gizem Karabulut for their enthusiastic help. 


\section{References}

Banhart, J. (2001). Manufacture, characterisation and application of cellular metals and metal foams. Progress in materials science, 46(6), 559-632.

Bekoz, N., \& Oktay, E. (2013). Effect of heat treatment on mechanical properties of low alloy steel foams. Materials \& Design, 51, 212-218.

Bekoz, N., \& Oktay, E. (2014). The role of pore wall microstructure and micropores on the mechanical properties of $\mathrm{Cu}-\mathrm{Ni}-\mathrm{Mo}$ based steel foams. Materials Science and Engineering: A, 612, 387-397.

Beköz Üllen, N., \& Karabulut, G. (2022). Production Techniques of Metallic Foams in Lightweight Materials. In Handbook of Research on Advancements in the Processing, Characterization, and Application of Lightweight Materials (pp. 153-175). IGI Global.

Guo, K., Li, M., Gong, Q., Li, C., Li, C., Zhong, H., \& Zhou, Y. (2016). Experimental investigation on steel foams fabricated by sintering-dissolution process. Materials and Manufacturing Processes, 31(12), 1597-1602.

Jain, H., Mondal, D. P., Gupta, G., Kumar, R., \& Singh, S. (2020). Synthesis and characterization of 316L stainless steel foam made through two different removal process of space holder method. Manufacturing Letters, 26, 33-36.

Javed, R., Rais, F., Fatima, H., ul Haq, I., Kaleem, M., Naz, S. S., \& Ao, Q. (2020). Chitosan encapsulated ZnO nanocomposites: Fabrication, characterization, and functionalization of bio-dental approaches. Materials Science and Engineering: C, 116, 111184.

Joshi, S., Gupta, G. K., Sharma, M., Telang, A., \& Mahra, T. (2015). Synthesis and Characterization of Stainless Steel Foam Via Powder Metallurgy Taking Acicular Urea As Space Holder. Material Science Research India, 12(1), 43-49.

Kolatoğlu, R., Aydin, E., Demir, M., Yildiz, A., Karakuş, S., Tüzün, E., ... \& Kilislioğlu, A. (2020). A Novel Electrochemical Sensor for the Detection of Reactive Red Dye to Determine Water Quality. In Advanced Functional Materials. IntechOpen.

Najm, S. S. (2021). Doping effect on the optical properties of (PVA: ZNO) nanocomposites. Materials Today: Proceedings.

Priya, A., Arumugam, M., Arunachalam, P., Al-Mayouf, A. M., Madhavan, J., Theerthagiri, J., \& Choi, M. Y. (2020). Fabrication of visible-light active $\mathrm{BiFeWO} / \mathrm{ZnO}$ nanocomposites with enhanced photocatalytic activity. Colloids and Surfaces A: Physicochemical and Engineering Aspects, 586, 124294.

Rajkumar, P., \& Sarma, B. K. (2021). Role of $\mathrm{Zn}$ and $\mathrm{Mg}$ substitutions on the mechanical behaviour of biomimetic hydroxyapatite and insight of the emergence of hydroxyapatite- $\mathrm{ZnO}$ Characterization, 176, 111107.

Rodríguez, R., Correcher, V., Gómez-Ros, J. M., Plaza, J. L., \& García-Guinea, J. (2021). Cathodoluminescence, SEM and EDX analysis of $\mathrm{CaF} 2$ and $\mathrm{Tm} 2 \mathrm{O} 3$ pellets for radiation dosimetry applications. Radiation Physics and Chemistry, 188, 109621.

Sazegaran, H. (2021). Investigation on Production Parameters of Steel Foam Manufactured Through Powder Metallurgical Space Holder Technique. Metals and Materials International, 27(9), 3371-3384.
Karakuş, S., Albayrak, İ., Üllen, N. B., Insel, M. A., Kilislioğlu, A. (2021). Preparation, characterization and evaluation of a novel CMC/Chitosan- $\alpha$-Fe 2 O 3 nanoparticles-coated 17-4 PH stainless-steel foam. Polymer Bulletin, 1-19.

Karakuş, S., Albayrak, İ., Beköz Üllen, N., İnsel, M., Kilislioğlu, A. (2020b). Mathematical Modelling of Surface Behaviors of ZnO Nanoparticles Coated 17-4 PH Stainless Steel Foam, 3rd International Conference on Physical Chemistry and Functional Materials (PCFM 2020), Malatya, Turkey, 22 - 24 September 2020, 33-39.

Karakuş, S., Beköz Üllen, N., Albayrak, F., İnsel, M.A., Kilislioğlu, A. (2020a). Optimization of Surface Properties of K-Carrageenan/PVA/Eggshell Nanobiocomposites Coated 17-4 PH Stainless Steel Foam, 3rd International Conference on Physical Chemistry and Functional Materials (PCFM 2020), Malatya, Turkey, 22 - 24 September 2020, 25-32

Singh, D., Kundu, V. S., \& Maan, A. S. (2016). Structural, morphological and gas sensing study of zinc doped tin oxide nanoparticles synthesized via hydrothermal technique. Journal of Molecular Structure, 1115, 250-257.

Shirzadi, A. A., Kocak, M., \& Wallach, E. R. (2004). Joining stainless steel metal foams. Science and technology of welding and joining, 9(3), 277-279.

Smith, B. H., Szyniszewski, S., Hajjar, J. F., Schafer, B. W., \& Arwade, S. R. (2012). Steel foam for structures: A review of applications, manufacturing and material properties. Journal of Constructional Steel Research, 71, 1-10.

Tariq, M., Khan, A. U., Rehman, A. U., Ullah, S., Jan, A. U., Khan, Z. U. H., ... \& Yuan, Q. (2021). Green synthesis of Zno@GO nanocomposite and its' efficient antibacterial activity. Photodiagnosis and photodynamic therapy, 35, 102471 .

Yang, C., Xie, D., \& Wang, S. (2021). Facile synthesis of palygorskite/polyaniline/ZnO nanocomposites as strong wideband microwave absorbers. Materials Letters, 131161.

Yu, C. J., Eifert, H. H., Knuewer, M., Weber, M., \& Baumeister, J. (1998). Investigation for the selection of foaming agents to produce steel foams. MRS Online Proceedings Library (OPL), 521

Welegergs, G. G., Akoba, R., Sacky, J., \& Nuru, Z. Y. (2021). Structural and optical properties of copper oxide $(\mathrm{CuO})$ nanocoatings as selective solar absorber. Materials Today: Proceedings, 36, 509-513.

Wagener, P., Faramarzi, S., Schwenke, A., Rosenfeld, R., \& Barcikowski, S. (2011). Photoluminescent zinc oxide polymer nanocomposites fabricated using picosecond laser ablation in an organic solvent. Applied surface science, 257(16), 7231-7237. 